\title{
The Fate of Subcutaneous Anorganic Bone Implants
}

John Peter Giannini

Loyola University Chicago

Follow this and additional works at: https://ecommons.luc.edu/luc_theses

Part of the Medicine and Health Sciences Commons

\section{Recommended Citation}

Giannini, John Peter, "The Fate of Subcutaneous Anorganic Bone Implants" (1961). Master's Theses. 1518.

https://ecommons.luc.edu/luc_theses/1518

This Thesis is brought to you for free and open access by the Theses and Dissertations at Loyola eCommons. It has been accepted for inclusion in Master's Theses by an authorized administrator of Loyola eCommons. For more information, please contact ecommons@luc.edu. (c) $($ ) $\Theta \Theta$

This work is licensed under a Creative Commons Attribution-Noncommercial-No Derivative Works 3.0 License. Copyright (C) 1961 John Peter Giannini 


\section{THE FATE OF SUBCUTANEOUS}

ANORGANIC BONE IMPLANTS

by

JOHN PETER GIANNINI

A Thesis Submitted to the Faculty of the Graduate School of Loyola University in Partial Fulfillment of the Requirements for the Degree of Master of Science JUNE 


\section{LIFE}

John Peter Giannini was born in Chicago, Illinois on October 27. 1930.

He was graduated from Charles P. Steinmetz High School and attended the Universities of Illinois and Loyola before entering Loyola University School of Dentistry in 1952. He was graduated in 1956 with the degree of Doctor of Dental Surgery. That same year he began graduate studies in Oral Anatomy and clinical studies in Oral Surgery. He served as instructor in Oral Surgery at Loyola University School of Dentistry in 1958, and was given a staff residency in Oral Surgery at Cook County Hospital in 1959.

In 1960 he was appointed to the staff of the Oak Park Hospital and was also made an associate attending oral surgeon at the Cook County Hospital. In addition he is an instructor of Gross Anatomy at Loyola University School of Dentistry and is engaged in the practice of Oral Surgery. 


\section{ACKNOWLEDGEMENTS}

In a man's formative years he is profoundly influenced and inspired by a few individuals. The ideals and standards which they represent are patterns he wishes to copy and attain in his own right. Three such men are Dr. Joseph Kostrubala, Dr. Patrick Toto, and Dr. Harry Sicher. I wish to thank them deeply for the personal help, patience, and guidance they gave me; and, also for that little portion of themselves which I will always retain as my own.

I also wish to thank Dr. Joseph Restarski for his help and guidance in the phocomicrography; and to Dr. Gustav Rapp for substituting in the oral examinations in Dr. Sicher's absence. I express my indebtedness to Mrs. Maria Gylys and her assistants for their excellent work on preparing the slides and special stains.

I extend my gratitude to Dr. Viggo Sorensen and Dr. Gilbert Carter for their personal interest and suggestions.

Finally to my patient wife, Doloree, whose persistance and assistance is responsible in part, for the completion of this work. 
TABLE OF CONTENTS

Chapter

Page

I. INTRODUCTION ............. 1

II. REVIEW OF LITERATURE ........... 3

III. MATERIALS ................. 9

IV. METHODS ................... 12

v. FINDINGS:

A. Connective Tissue Reaction ........ 14

B. Changes of Implant ......... 15

v1. DISCUSSION .............. 17

vII. SUMMARY AND CONCLUSIONS ........ 20

vIII. BIBLIOGRAPHY . . . . . . . . . . 22

IX. APPENDICIES. ............. 25 


\section{CHARTER I \\ INTRODUCTION}

Much work has been done and many theories proposed on the subject of bone growth and absorption, but in spite of the ancient attack of the problem confusion and controversy seem to be the only consistent facts evolved. A material almost entirely free of organic matrix has been used here with hopes of clarification of those theories.

In bone resorption, it is generally believed that osteoclasts remove the organix matrix. The mineral element is liberated into the tissue fluids. With this new material, perhaps we can show the exact nature of bone resorption and the cells responsible for that fate. Moreover, this "anorganic" bone may be valuable in the mobilization of osteoclasts in a non-bony connective tissue environment. 3y using oher types of implants we may compare, also, the osteoclastic inducing properties.

In the problem of bone growth and induction, there is the question of inherent ability of anorganic bone to induce osteoblastic production in connective tissue.

The organic free state of this bone is another question which presents itself. The fact that anorganic bone retains its bone organ 
form following chelation suggests that the mineral components are bound only by molecular crystalline continuity. However, it is possible that there may be a residual mucopolysaccharide matrix binding the mineral component of anorganic bone.

To answer some of the questions of the fate of anorganic bone, subcutaneous implants were studied in the undecalcified state. 


\section{CHAPTER II \\ REVIEW OF LITERATURE}

The first really scientific approach to the problems of bone growth and resorption was made by Ollier in 1858 , although Duhamel (1739), who placed silver wires subperiosteally believed that the new bone which covered the wires was produced through the osteogenic properties of the periosteum, and Von Haller (1763), who regarded the periosteum as being the support for the blood vessels which were the agents for osteogenesis in healing of fractures, divided two schools of thought before that time. In 1867, at the conclusion of his experiments, Ollier concluded that transplanted periosteum and bone remained alive and could under proper circumstances become osteogenic. The contents of the Haversian canals and the endosteum were also important in bone regeneration.

From 1893 to 1898 another controversy arose when numerous papers by Barth claimed that all transplanted bone, marrow, and periosteum die and are replaced by the surrounding tissue.

Axhausen (1901-09) made a major contribution to the problem of osteogenesis and bone transplantation when he formulated his well known 
principles that periosteum has a high degree of survival and osteogenic activity in autogenous grafts, markedly less in homografts, and practically none in heterogenous transplants. His work was done with rabbits and rats and later with humans. He believed that all transplanted bone dies but that most of the periosteum on the periosteally covered transplants is a source of osteogenesis. His work has been substantiated and is largely accepted today.

Since the advent of Axhausen's findings, many men have concerned themselves with the bone itself rather than the periosteum. Another bitter controversy arose when some contended that bone developed from metaplasia of cells of the surrounding connective tissue while others believed that the soft tissue of the bone itself is responsible for osteogenesis. Today, although not adequately settled, the proponents of the metaplasia theory are more prominent.

Studies in stimulation of osteogenesis, which began with Nokahara and Dilger (1909), Sasoki (1911), and Jokai (1912), attempted to produce an organizer from extracts and emulsions of bone and periosteum. No one has been able to show evidence of a specific chemical osteogenic organizer. Levander (1940) made subcutaneous autogenous transplants of 
bone marrow in rabbits and obtained bone formation. His findings showed that the mesenchymal tissue surrounding the marrow had been induced to form bone by some osteogenic substance in the marrow. Pfeiffer (1948), among others, demonstrated osteogenesis in the anterior chamber of the eye of a mouse and also in the testes of mice, and here too the feasibility of an organizer substance is apparent but not proved. The fate of bone grafts, as generally agreed upon today, is little changed from Axhausen's original observations. The periosteum mainly survives and retains its osteogenic properties while most of the bone and marrow die. Connective tissue invades from host and implanted periosteum, host marrow, and some of the host's surrounding tissue to institute repair and reorganization. This vascular, delicate tissue of repair is transformed to become locally osteoblastic or osteuclastic and reorganIzation of cancellous and compact bone is completed. Myeloid and fatty marrow is a subsequent conversion of this tissue also. Axhausen's other views on the fact of autografts being highly acceptable in comparison to homografts and heterografts is still generally agreed upon today. Recent development of "anorganic" bone has in its young life, caused much excitement in realization of a readily available substitute 
with all the properties of an autotransplant. Even heterologous transplants, as shown by Hufley and Losee (1956), were successfully accepted in over eighty transplants. The site used was the tibia in dogs; and cortical inlay grafts showed host acceptance regardless of species source. Moreover, the graft remodeled and revascularized itself similar to an autogenous graft. In all their implants, ethylenedimine treated bone showed lack of foreign body reaction, little callus formation, mineral bonding between donor and host bone, early revascularization, and reactive new bone formation.

Boyne and Losee (1957), demonstrated the successful use of anorganic bone in iatrogenic defects of the jaws of monkeys. The implanted graft particles were accepted by the host tissue. They were evaluated clinically, radiographically, and histologically. Reactive bone formation surrounding the implants was demonstrated as early as the thirteenth post-operative day. Later works by the same authors (using fifty subjects), showed acceptance in human jaw defects such as bone cysts, periapical defects, jaw reconstruction, and alveoloplasty. Host acceptance and absence of foreign body reaction were clinically observed for six to twelve months post-operatively. 
Cross (1957), demonstrated the use of anorganic bone in periodontal disease; and in four cases showed radiographic evidence of two successful implants after four and seven months.

Melcher (1958), utilized anorganic bone in alveolar resorption caused by periodontal disease. The heterogenous transplant was found to be wholly acceptable to periodontal tissues with varying amounts of regeneration of alveolar bone.

Bell, Hinds, and Arnim (1958), placed bovine and anorganic bone chips into extraction sites of human patients. Controls were used by allowing some of the sockets to fill with blood. Bipsies taken after two weeks showed moderate to severe inflammatory and foreign body reaction in the sockets containing bovine chips. Biopsies from the anorganic bone sites showed considerably less inflammatory reaction and as healing progressed, new bone surrounded remnants of the anorganic bone chips. Their results demonstrate better acceptance of anorganic bone by the host.

Anorganic bone as a grafting material in the correction of micrognathia has been used by Hayward, Costich, and Avery (1958). They reported formation of new bone between the particles of the anorganic 
matrix. Their results were determined by radiographic examination. They also eliminated undesirable undercuts of alveolar ridges by anorganic bone grafts. They report no post-operative complications attributed to the grafts. 


\section{CHAPTER III}

\section{MATERIALS}

This investigation was conducted on forty young male albino mice weighing approximately twenty to twenty-five grams. The materials implanted were: freshly boiled beef bone (cancellous), isologous mouse rib (obtained from freshly sacrificed litter mates), and bovine anorganic bone (forty mesh).

The anorganic or ethylenediamine treated bone is obtained in the following manner. Bone is placed into pyrex fritted extraction thimbles. Large particles are placed in coarse-fritted glass, and minute particles over very fine-fritted glass. The thimbles are inserted into a modified soxhlet extractor where its position is such that the samples are kept within one degree of the cycling liquid's temperature by the vapors of the boiling liquid surrounding the material.

The organic solvent is constant boiling ethylene-diamine $\left(\mathrm{NH}_{2} \mathrm{CH}_{2} \mathrm{CH}_{2} \mathrm{NH}_{2}\right)$. This fraction is collected between 117.5 and 118.5 degrees Centigrade from a solution of distilled water and $95-100 \%$ ethylenediamine, (1 to 4). The resultant organic solvent is clear and 
colorless.

The time for extraction is 32 to 36 hours for a single 5 gram piece of femoral cortical bone dried in vacuo and extracted with $150 \mathrm{ml}$. of ethylenediamine. Subsequent to the ethylenediamine treatment the bone is rinsed several times with room temperature distilled water to remove the water-soluble ethylenediamine and carbonic acid salt of ethylenediamine formed from the combination with atmospheric $\mathrm{CC}_{2}$. This is followed by six one-hour water extractions with multiple room temperature rinses between each extraction period. The purity is checked by ultraviolet absorption spectra and $\mathrm{pH}$ determinations since ethylenediamine has a characteristic absorption peak and is extremely alkaline.

The ethylenediamine extracted bone is either air-dried, dried in vacuo, or placed in physiological saline or alcohol for storage until ready for use. No attempt is made to keep the bone sterile, since it can be autoclaved without altering either structure or function.

Bone after ethylenediamine treatment and six water rinses has less than $0.1 \%$ Nitrogen. Yet, when the nitrogenous organic matrix is removed from the bone, no apparent change in gross morphology is seen. 
If a fresh bone is demineralized by chelation, the remaining organic matrix retains the original whole bone morphology. If the organic component is necessary for binding, one would expect that the bone would tend to crumble on removal of the organic matrix, which it does not do. 


\section{CHAPTER IV \\ METHODS}

Surgery was performed on the mice by first shaving the interscapular area and then making a one-centimeter incisicn through tive skin. The loosely attached skin was elevated exposing the loose connective tissue. Forty mesh anorganic bone was implanted about one centimeter distal to the line of incision. A similar procedure was followed using fresh boiled beef bone spicules and spicules of isologous mouse rib. These subcutaneous implants served as local controls. The incision was closed with two or three 000 black silk sutures. The procedure was performed under general anesthesia using ether in a glass enclosure. The post-operative course was uneventful, and clinically, there was no difference in the implant sites.

The mice were sacrificed at intervals as follows:

$\begin{array}{lll}\text { Period I } & 4 \text { mice } & 24 \text { hours } \\ & 4 \text { mice } & 36 \text { hours } \\ & 4 \text { mice } & 72 \text { hours } \\ & 4 \text { mice } & 7 \text { days } \\ \text { Period II } & 4 \text { mice } & 1 \text { month } \\ & 4 \text { mice } & 2 \text { months } \\ & 4 \text { mice } & 3 \text { months }\end{array}$




$\begin{array}{lll}\text { Period III } 4 \text { mice } & 4 \text { months } \\ & 4 \text { mice } & 5 \text { months } \\ 4 \text { mice } & 6 \text { months }\end{array}$

The skin of the implant site was excised en-block and fixed in $10 \%$ formalin. The tissue, subsequently, was imbedded in celloidin and sectioned at six microns. All of the specimens were imbedded and sectioned in the undecalcified state. The sections were stained for phosphate by the method of von Kossa; for mucopolysaccharides by the Periodic Acid-Shiff modified by Coleman, and for routine examination by hematoxylin and eosin. 


\section{CHAFTER V}

\section{FINDINGS}

A. Connective Tissue Reaction

The following findings characterize the reaction to implants through the first week, (Period I). The subcutaneous tissue reaction to the implants of anorganic bone, heterologous bone, and isologous bone is so similar as to be almost identical. At three days, a connective tissue capsule is formed around each of the implants. The capsule is highly cellular, containing many young fibroblasts, histiocytes, and many thinwalled cappillaries. A syncytium of histiocytes is always found immediately adjacent to the surfaces of, and completely surrounding each implant. The delicate fibrils between the fibroblasts of the capsule are few in number. The only difference in the connective tissue reaction to the different implants is the presence of polymorphonuclear leucocytes in moderate numbers around heterologous bone implants and their scarcity around isologous bone implants. The capsule around the anorganic bone implants is free of polymorphonuclear leucocytes.

Little change occurs in the capsule during the first, second, and 
third months, (Period II). There is maturation of the capsule characterIzed by some reduction in the cellularity with increased collagenization and reduction in vascularity. Also, there is a reduction of the polymorphonuclear leucocyte infiltration; histiocytes, resembling foreign body giant cells, still surround the surface of each implant.

The capsule continues its maturation by increased collagenization and reduction in cellularity and vascularity, during the fourth, fifth, and sixth months, (Period III). At six months, the capsule is well collagenized. The polymorphonuclear leucocyte infiltration of the capsule is only slight in the heterologous bone, and absent in the anorganic bone, and isologous mouse bone implants. However, the syncytium of histlocytes and foreign body type giant cells persist on the surface of the implants. Howship's lacunae were observed on each of the implant surfaces during the late stages of observation, (Period III).

B. Changes of Implant

The matrix of anorganic bone, heterologous bone, and isologous bone contains mucopolysaccharides as seen in sections stained by the Periodic Acid - Shiff method during the entire experimental period. 
During the first period (first week), in all of the sections stained for insoluble calcium phosphates, the implants stain uniformly black. At three days, anorganic bone appears as dense black clumps, irregular particles, and granules. The granules represent the "dust" of the soft anorganic bone rubbed off at the time of implantation. The heterologous bone and isologous bone appear as black spicules of lamellated bone tissue.

In the second period, (one, two and three months) the dust particles are lost. The center of the particles of anorganic bone is deep black. Toward the periphery it assumes an orange hue; the margins are transparent. The isologous bone and heterologous bone stain uniformly black.

During the third period, (four, five and six months) the sections stained for insoluble calcium phosphates show considerable differences. The anorganic bone appears as transparent matrix with orange - black centers; smaller particles are completely transparent. The isologous implants stain uniformly black, but the heterologous implants show at their periphery a narrow, orange appearing, transparent band. 


\section{CHAPTER VI \\ DISCUSSION}

The study of implants of small particles of anorganic bone into the subcutaneous tissue of mice in undecalcified sections serves as a useful technique to study the fate of the implants. Only this method allows a realistic and complete elucidation of the fate of anorganic bone.

Boyne and Losee mainly studied intraosseous implants of anorganic bone. However, in one series, anorganic bone was implanted into the abdominal wall. The intraosseous implant of anorganic bone was reported to serve as a nidus for bone apposition. New bone was observed to form around the implant. Also, it was reported that the anorganic bone was removed by osteoclastic resorption. Implants into the abdominal wall were not present after six months. Presumably, they had undergone resorption.

The use of anorganic bone as an agent to stimulate bone formation in bony defects such as cyst spaces after cystectomy followed the experimental study. It is evident from our experiments that anorganic bone, 
per se, does not induce formation of bone in the subcutaneous tissue. Instead the implant is surrounded by, and in immediate contact with a syncytium of histiocytes. Small defects on the surfaces of the implants resemble, but cannot be interpreted as, Howship's lacunae. A cellular and vascular capsule further walls the implant off from the connective tissue of the implant site. The only changes in the capsule are an Increase in collagenization associated with a reduction in cellularity.

It seems clear that all the implants caused a reaction comparable to a foreign body reaction. The histiocytic syncytium and the capsule substantiate this interpretation. The polymorphonuclear leucocyte infiltration, especially in heterologous bone implants, also supports this interpretation.

A fibrovascular capsule, in addition to the histiocytes, effectively walls off implants of anorganic bone. The inorganic salts leach out of the implant into the fluid system of the capsule. No doubt, this is possible because the amount of organic matrix in anorganic bone cannot effectively bind the salts in a tissue fluid medium. At no time, except during the initial stages, before a capsule can be formed does the leached out salts diffuse beyond the limits of the capsule. Limiting 
influence of the capsule is interpreted as regulating the rate at which the salts may be absorbed into the blood stream. The mineral loss, namely the reduction in phosphate and the associated calcium in the implants is seen as a function of time. In all the anorganic bone implants, the loss of bone salts proceeded from the periphery. No positive reaction for insoluble calcium phosphate was seen in the histiocytes. Furthermore, there was no associated loss of matrix as the phosphate negative periphery widens as the salts are lost.

The bone salt loss in heterologous bone is much less than in anorganic bone, no doubt due to the greater amount of organic matrix and resistance to osteoclastic resorption. Boiling of the bone denatures the matrix which may account for the resistance to resorption and permits some loss of bone salts from the periphery. The isologous bone which was not denatured did not show this loss from the periphery, but does show loss of bone by osteoclastic resorption. Therefore, it is felt that denaturization of bone causes resistance to resorption in both anorganic and heterologous bone and permits some direct loss of bone salts into the tissue fluids. 


\section{CHAPTER VII}

\section{SUMMARY AND CONCLUSIONS}

Forty mice were used for the subcutaneous implantation of forty mesh anorganic bone, heterologous boiled beef bone, and isologous mouse bone. Histologic study of the undecalciffed implants were done on twenty-four hour through six month specimens. Special stains, von Kossa for insoluble calcium phosphates and Periodic Acid-Shiff for mucopolysaccharides were used.

The anorganic bone is surrounded by a cellular and vascular capsule. Histiocytes are elaborated from undifferentiated connective tissue and come into immediate surface contact and envelop the implant.

The mineral salts of the implant leach out into the tissue fluid. This is due to the reduced amount of anorganic matrix capable of binding the salts in a fluid system. In time, the periphery of the implant loses completely its mineral content while the central areas still retain some. At six months some implant particles were completely free of salts. Yet, the matrix remains surrounded by a syncytium of histiocytes and a capsule. Rarely, a surface defect in the implant 
resembling a Howship's lacunae was seen. The capsule served to control the removal of leached out salts and to wall off the matrix from the connective tissue of the implant site. In effect the capsule is a physiologic barrier to regulate the absorption of high concentration of minerals, a histologic barrier walling off foreign protein matrix, and a phagocytic organ of low activity.

Isologous mouse bone and heterologous beef bone induce a reaction similar to anorganic bone. The polymorphonuclear leucocyte infiltration which accompanies heterologous bone and persists for six months appears as a classic foreign body reaction. However, both anorganic bone and isologous bone likewise show evidence of the foreign body reaction.

Anorganic bone does not show any bone inducing properties. Moreover, it is not resorbed over a period of six months, and therefore, demonstrates very little if any osteoclaskic inductive property. 


\section{BIBLIOGRAPHY}

Axhausen, G. Histologische Untersuchungen uber Knockentransplantation am Menschen. Deutsche Zeitsche f. Chir., 91:388-428, 1907.

Axhausen, G. Die Histologischen und Klinischen Gesetze der freien Osteoplastik auf Grund von Thierversuchen. Arch. f. Klin. Chir., 88: 23-145, 1909.

Barth, A. Uber Histologische Befunde nach Knockenimplantationen. Arch. f. Klin. Chir., 46:409-417, 1893.

Barth, A. Uber Osteoplastik. Arch. f. Klin. Chir., 86:859-872, 1908.

Bell, W. H., Hinds, E. C., and Arnim, S. S. Histologic Comparison of Bovine and Anorganic Bone Implants in Human Beings. Journ. of Dental Research 37, 45, Feb. , 1958 (Item 10).

Boyne, P. J. , and Losee, F. L. Response of Oral Tissues to Grafts of Ethylenediamine-Treated Heterogenous Bone. Research Report NM 0040060902 , Naval Medical Research Institute, Bethesda, Maryland, May 3, 1957.

Boyne, P. J., and Losee, F. L. Use of Anorganic Bone in Oral Bony Defects. U. S. Armed Forces Medical Journal 8, 789-794, June, 1957.

Cross, W. G. Bone Implants in Periodontal Diseases - A Further Study. Journal of Periodontology 28, 184-191, July, 1957.

Hayward, J. R., Costich, E. R., and Avery, J. K. The Use of Inorganic Beef Bone Matrix in Oral Surgery. Journal of Dental Research 37, 46, Feb. , 1958 (Item 112).

Jokai, T. Experimenteller Beitrag zur Knocken-Neublldung durch Injektion bzw. Implantation von Periosteumulsion. Deutsche Zeitschr. f. Chir., 118: 433-443, 1912. 
Kiehn, C. L., Cebul, F., Berg, M., Gutentag, J., and Glover, D. M. A Study of the Vascularization of Experimental Bone Grafts by Means of Radioactive Phosphorus and the Transparent Chamber. Ann. Surg. , 136: 404-411, 1952.

Kirby-Smith, H. T. Bone Growth Studies -- A Miniature Bone Fracture Observed Microscopically in a Transparent Chamber Introduced in a Rabbit's Ear. Am. J. Anat., 53:377-402, 1933.

Levander, G. An Experimental Study of the Role of Bone Marrow in Bone Regeneration. Acta. Chir. Scandinavica. 83:545-560, 1940.

Losee, F. L., and Hurley, L. A. A Successful Cross-species Bone Grafting Accomplished by Removal of Donor Organic Matrix. Research Report NM 004006.09 . o1, 14:911, 1956, Bethesda, Maryland.

Losee, F. L. Personal Communication.

McLean, F. C. Physiology of Bone. Am. Reo-Physiol., 5:79-104, 1943.

Melcher, A. M. The Use of Heterogenous Anorganic Bone In Feriodontal Bone Grafting. Journal of the Dental Ass'n. of South Africa 13, (3), 80 (1958).

Nakohara, T., and Dilger, A. Subkutane und Intermuskulare Knochenneubildungen durch Injektion bezw. Implantation von Periostemulsion. Beitr. z. Klin. Chir., 63:235-243, 1909.

Pfeiffer, C. A. Development of Bone from Transplanted Marrow in Mice. Anat. Rec. , 102: 225-243, 1948.

Urist, M. R., and McLean, F. C. Osteogenic Potency and New Bone Formation by Induction in Transplants to the Anterior Chamber of the Eye. Journal of Bone and Joint Surgery, 34-A:443-476, 1952.

Urist, M. R. and McLean, F. C. The Local Physiology of Bone Repalr with Particular Reference to the Process of New Bone Formation by Induction. Am. J. Surg. , 85: 445-449, 1953. 
Weinmann, J. P., and Sicher, H. Bone and Bones, 2nd Edition, St. Louis, C. V. Mosby, 1955.

Williams, J. B., and Irvine, J. W. Science., 119-771, 1954. 
Figure 1

Autopsy specimen showing encapsulated bone implants In loose connective tissue. 
CHAPTER IX

\section{APPENDICIES}

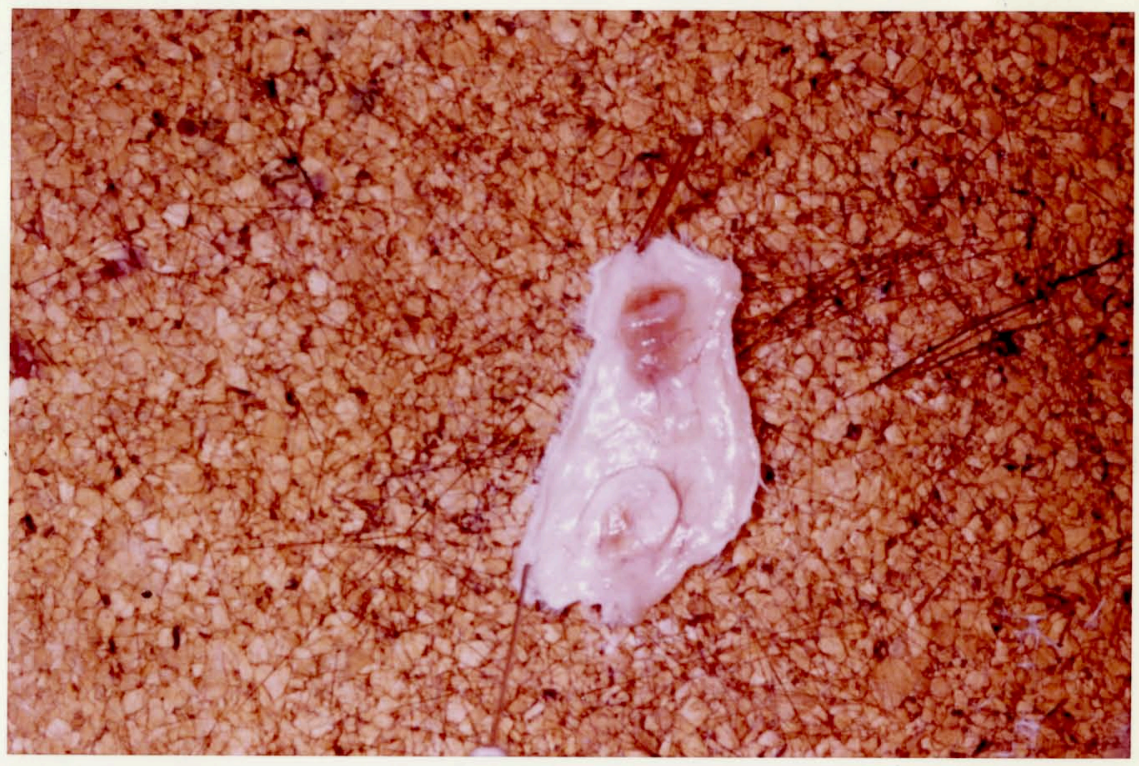

Figure 1 
Figures 2 and 3

Connective tissue capsule seen around anorganic bone (above) and heterologous beef bone. 


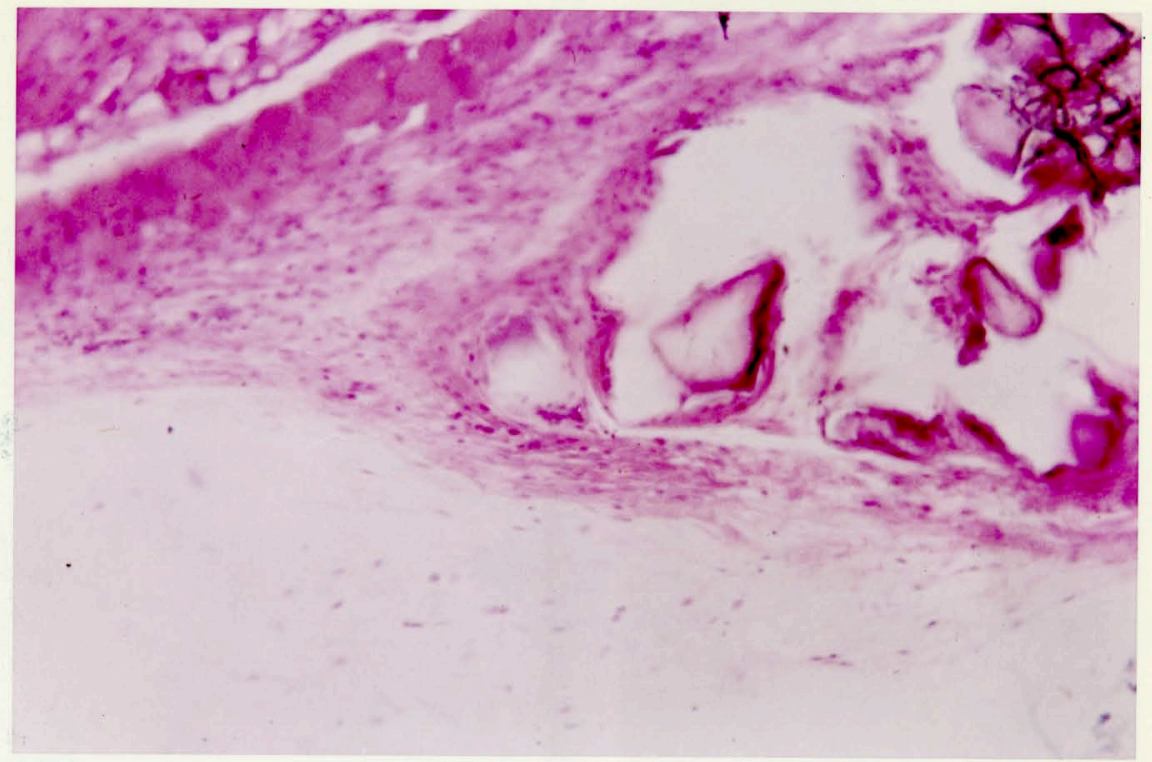

Figure 2

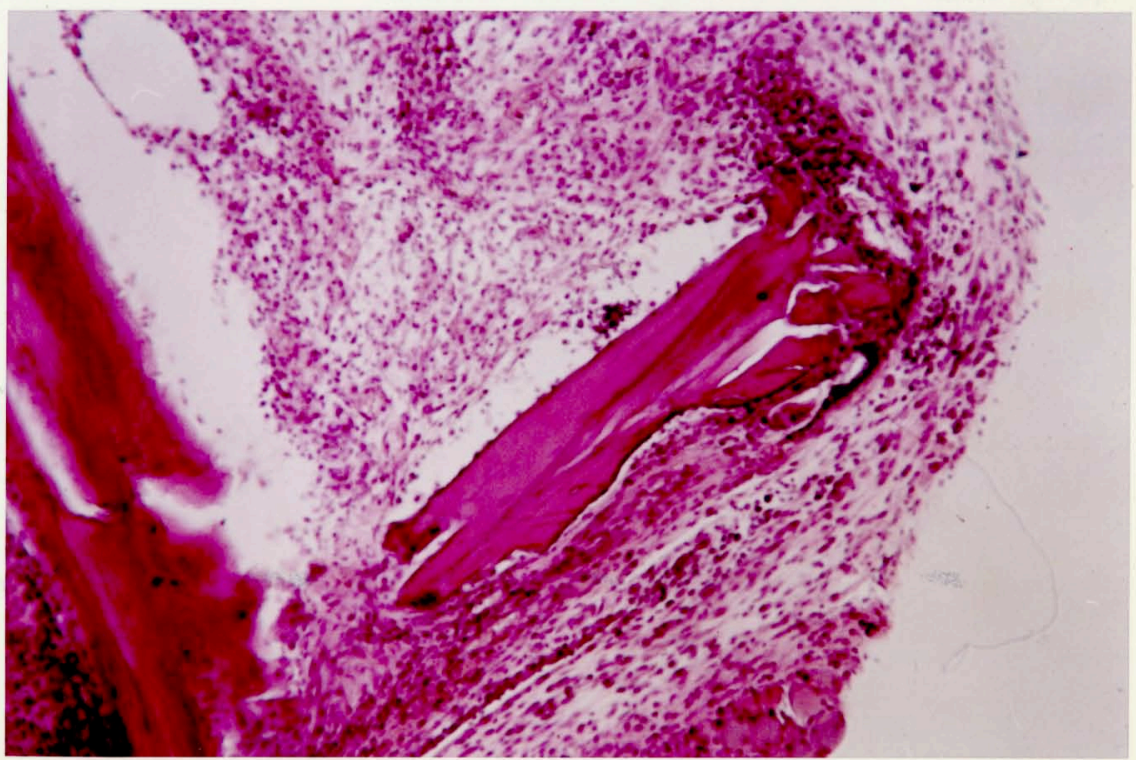

Figure 3 
Figures 4,5 and 6

Anorganic bone, isologous mouse bone, and heterologous beef bone implants showing degrees of connective tissue reaction and polymorphonuclear leucocyte infiltration (hematoxylin and eosin). 


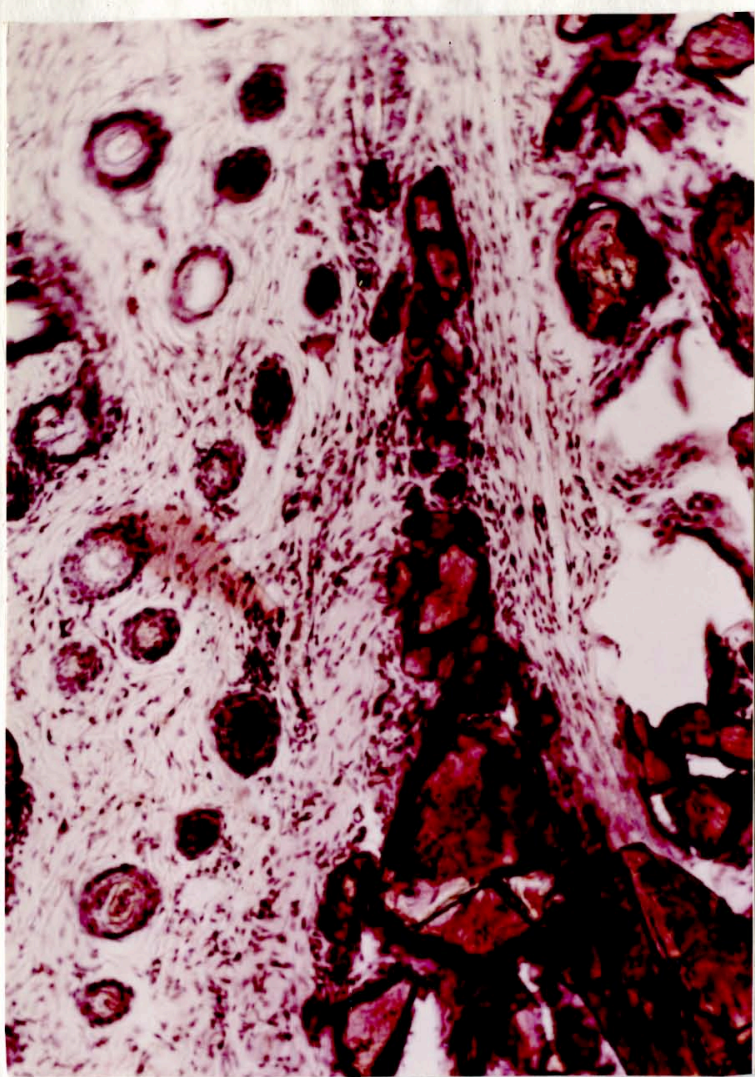

Figure 4

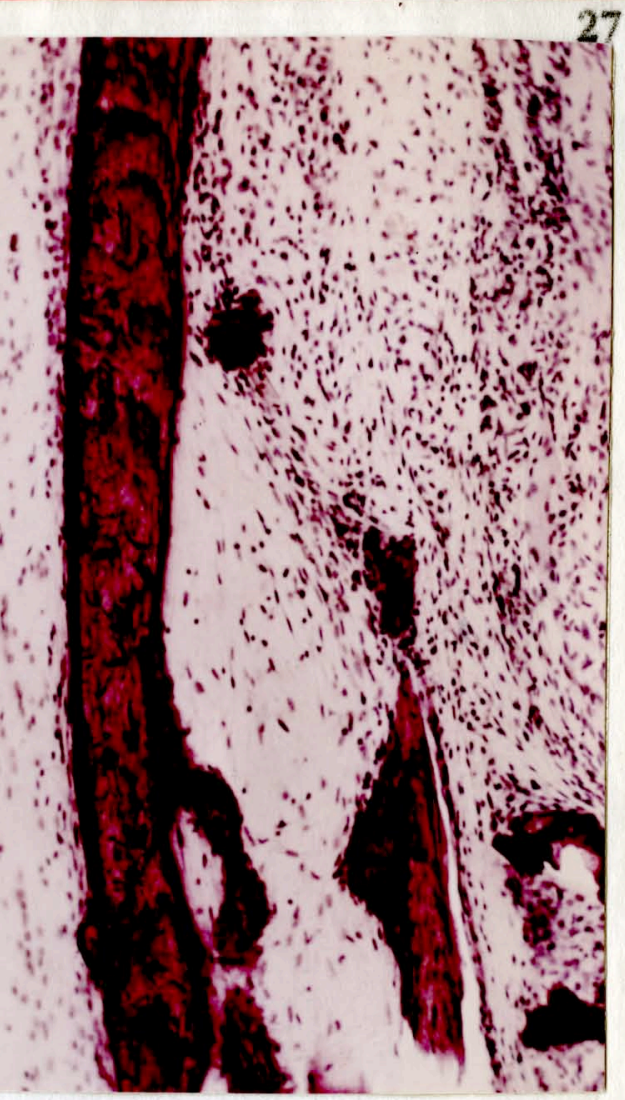

Figure 5

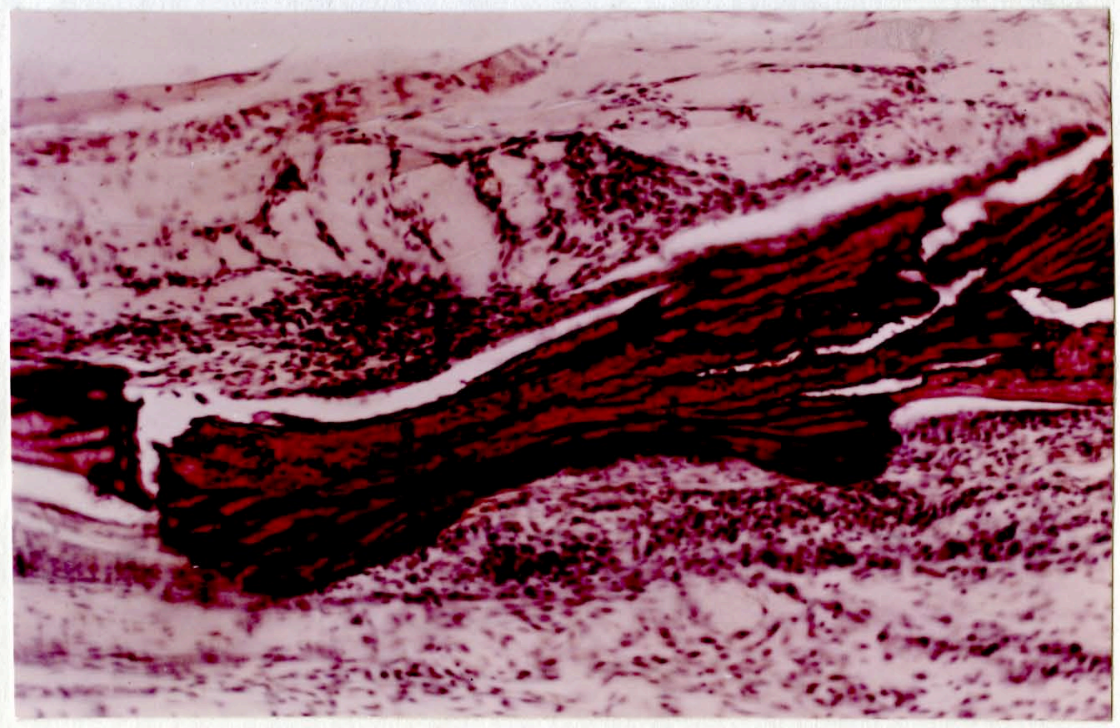

Figure 6 


\section{Figure 7}

Anorganic bone stained for mucopolysaccharides by Periodic acid-schiff method showing positive reaction. 
Figure 7 


\section{Figures 8 and 9}

Anorganic bone stained by von Kossa method at three days demonstrating liberated granules. 


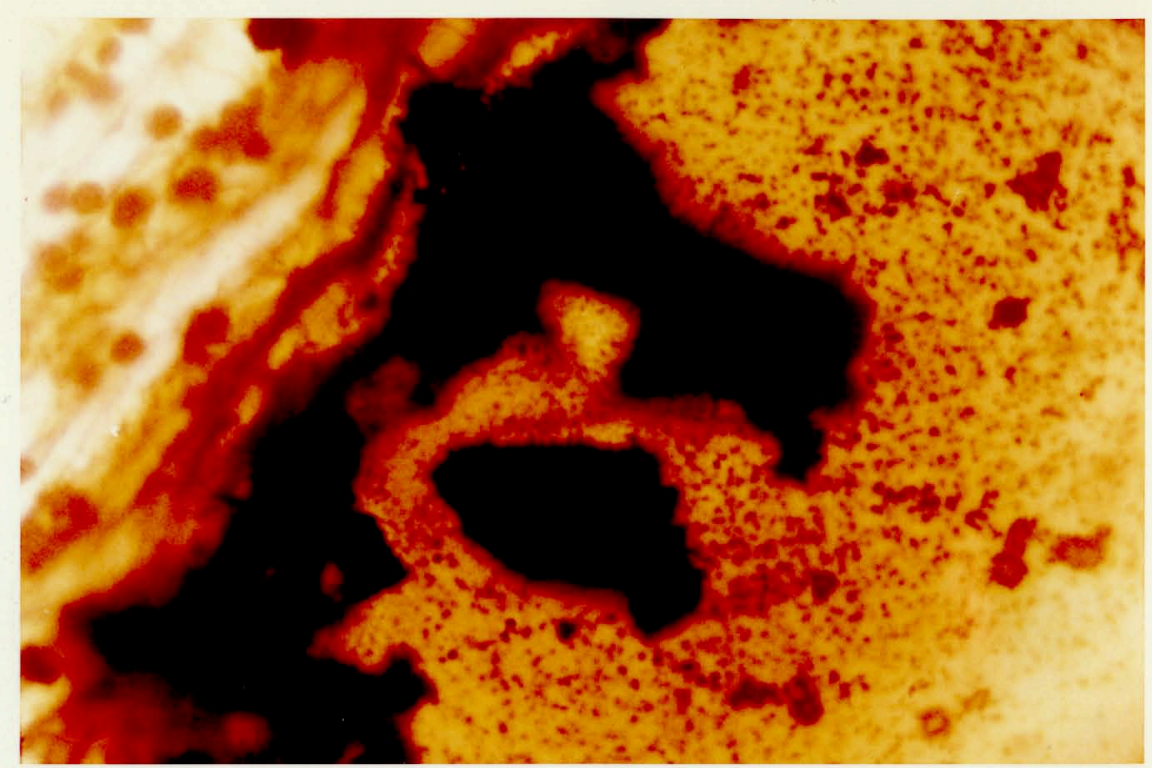

Figure 8

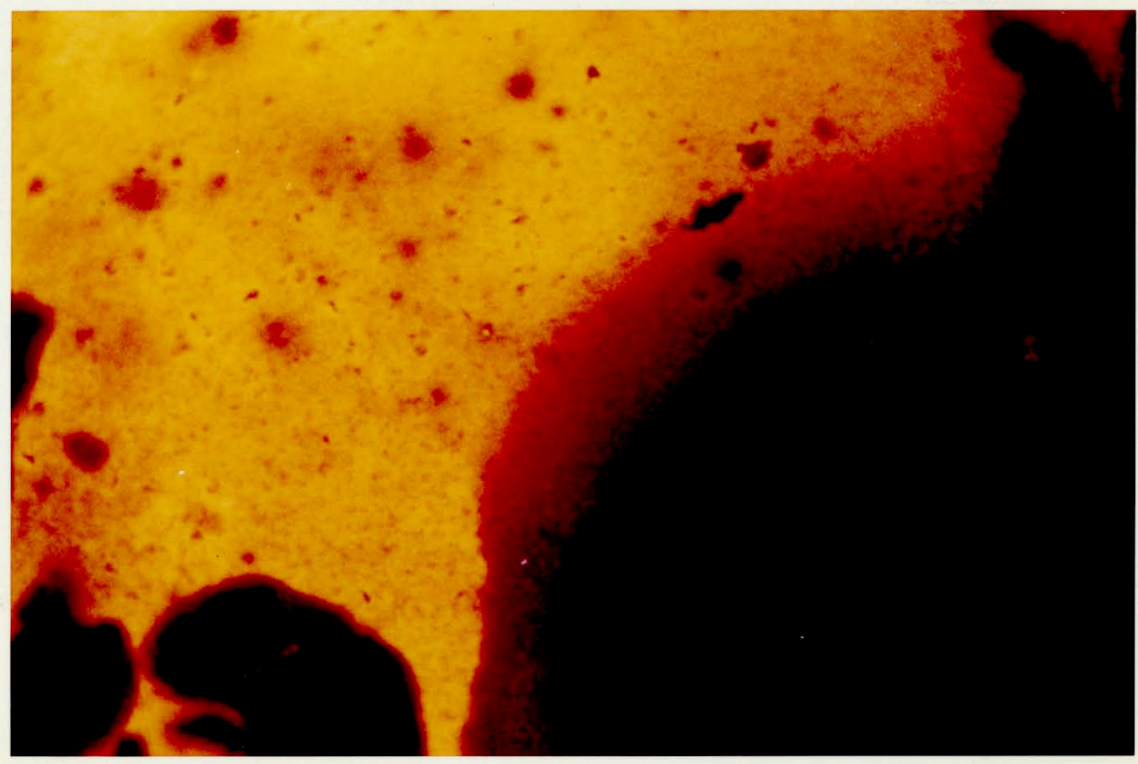

Figure 9 


\section{Figures 10 and 11}

Anorganic bone stained by von Kossa method in second period indicating the progressive loss of bone salts. 


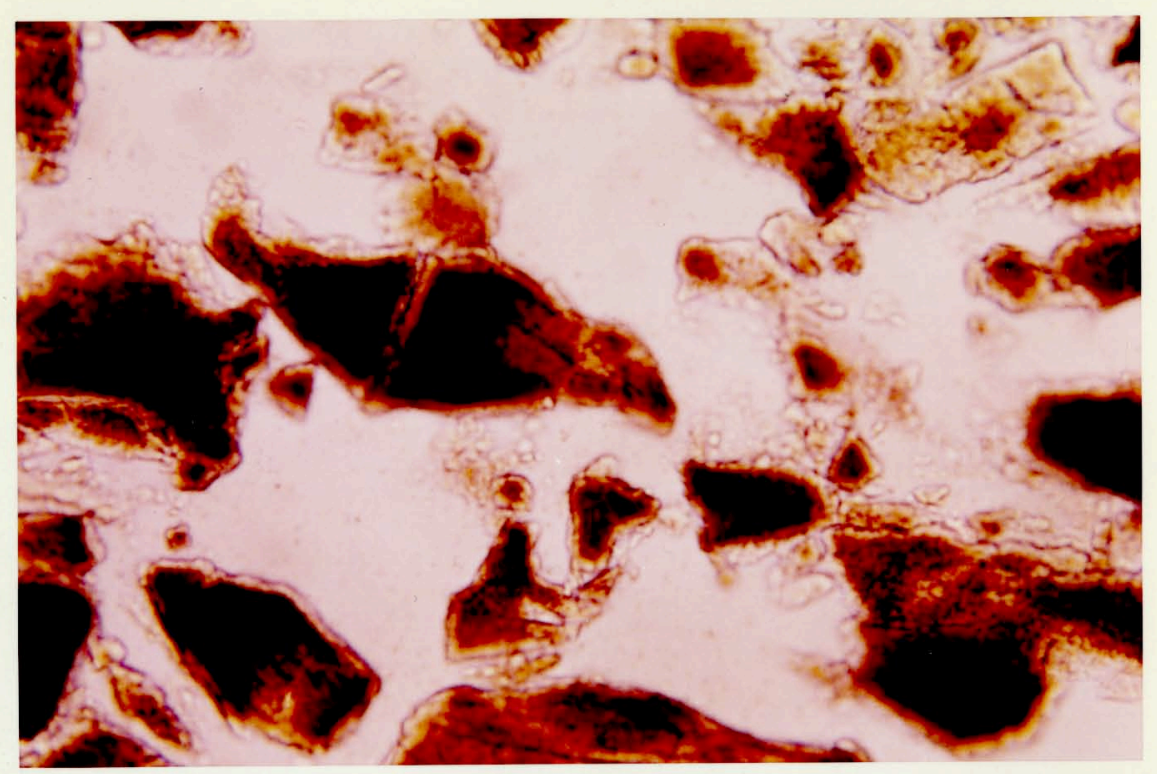

Figure 10

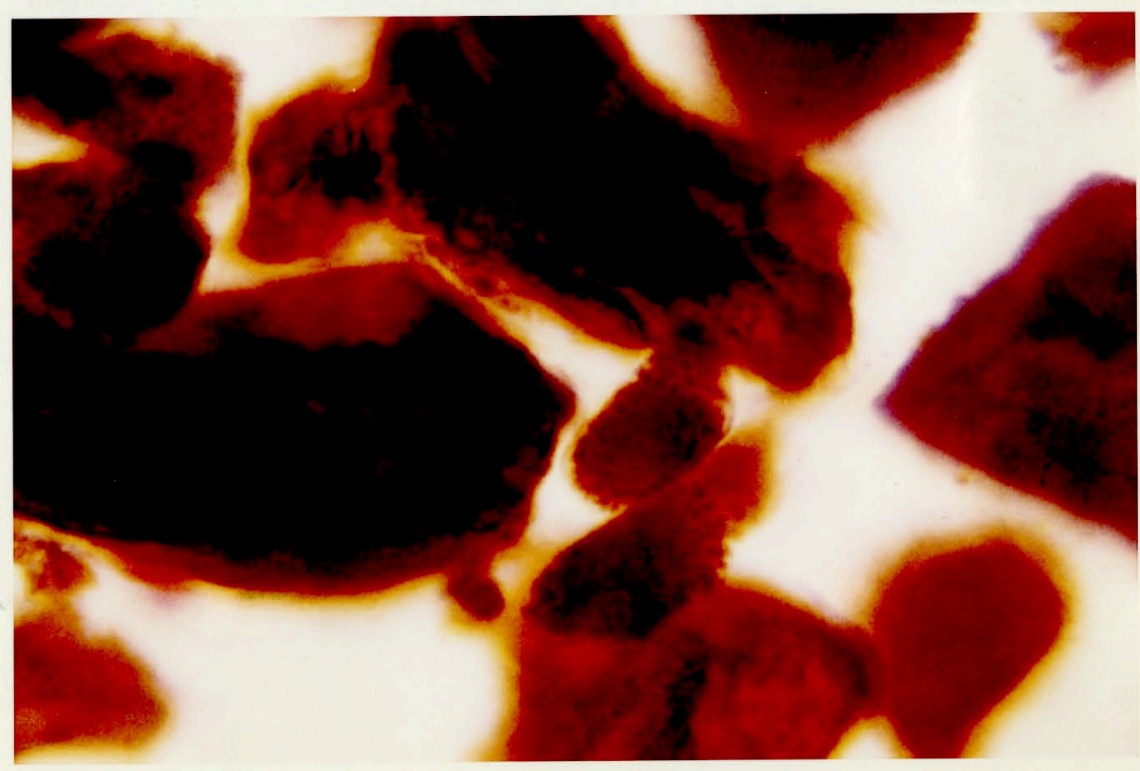

Figure 11 
Figure 12

Heterologous beef bone stained by von Kossa method. The orange pertphery indicates loss of bone salts (second period).

Figure 13

Isologous mouse bone staining uniformly black (second perlod). 

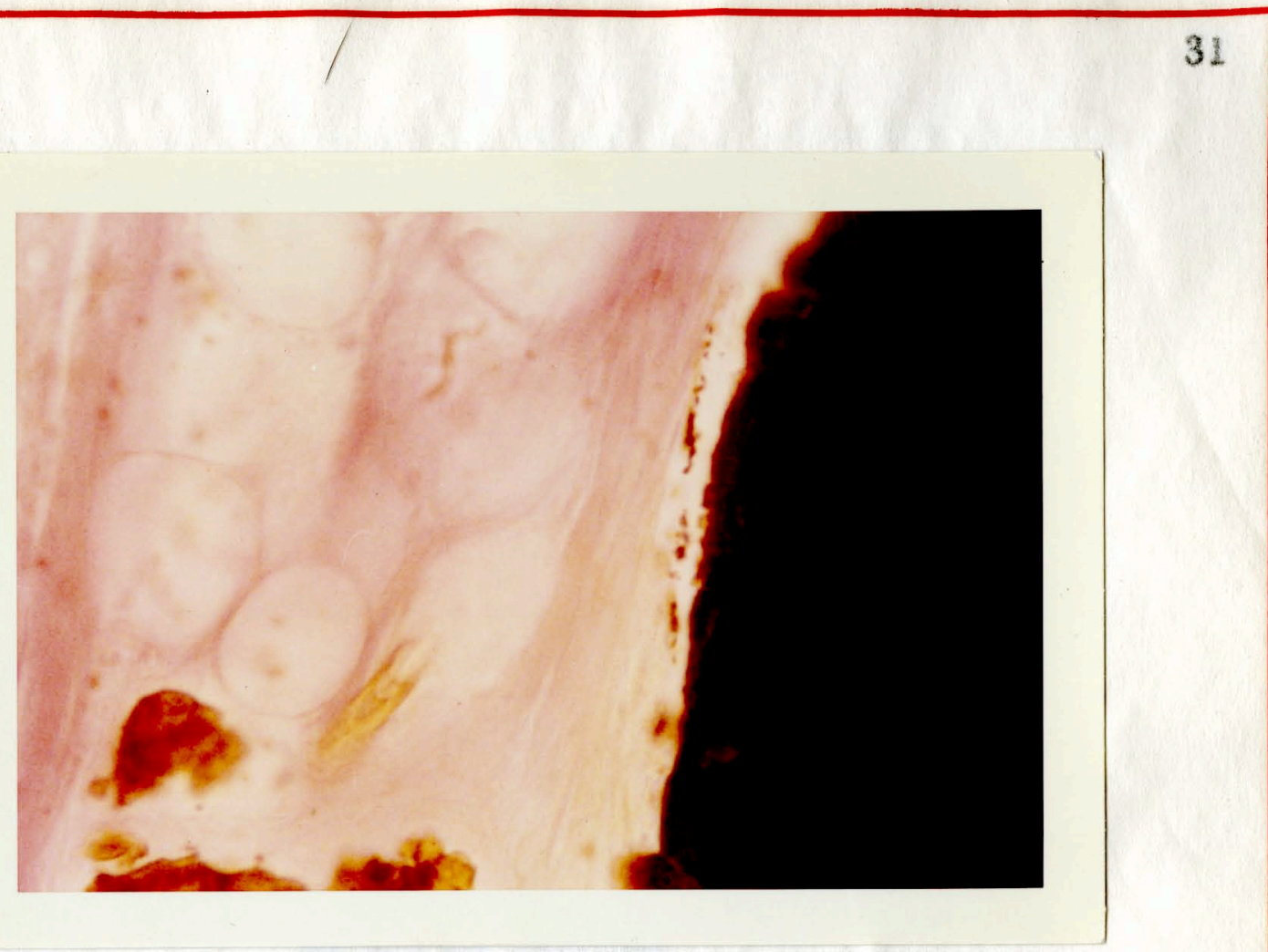

Figure 12

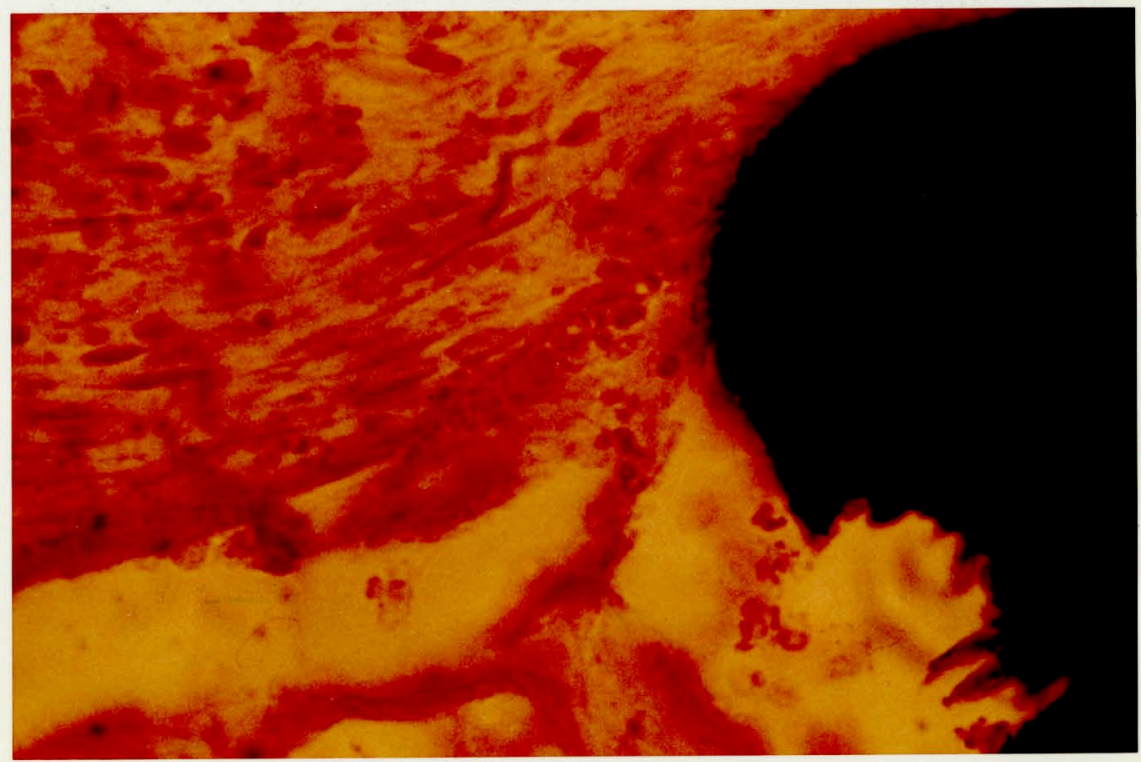

Figure 13 
Figures 14 and 15

Isologous mouse bone stained by hematoxylin and eosin demonstrating osteoclastic resorption (second period). 


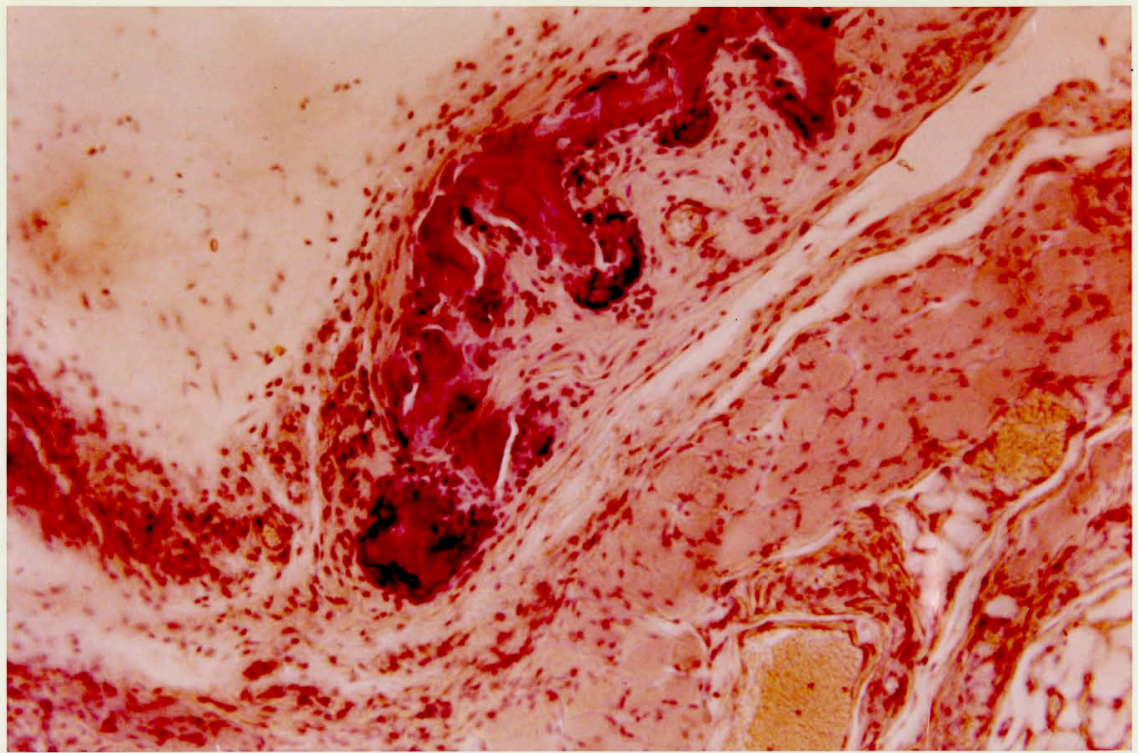

Figure 14

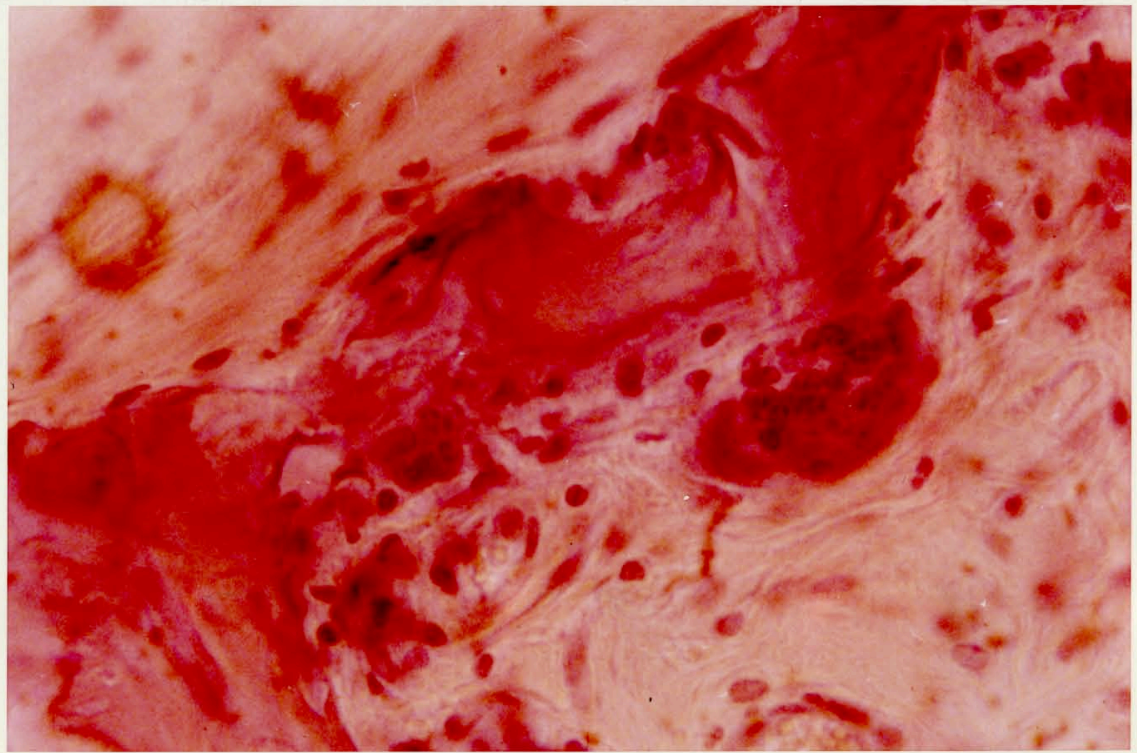

Figure 15 
Figures 16 and 17

Anorganic bone stained by von Kossa during third period. NOTE: Transparent matrix. 


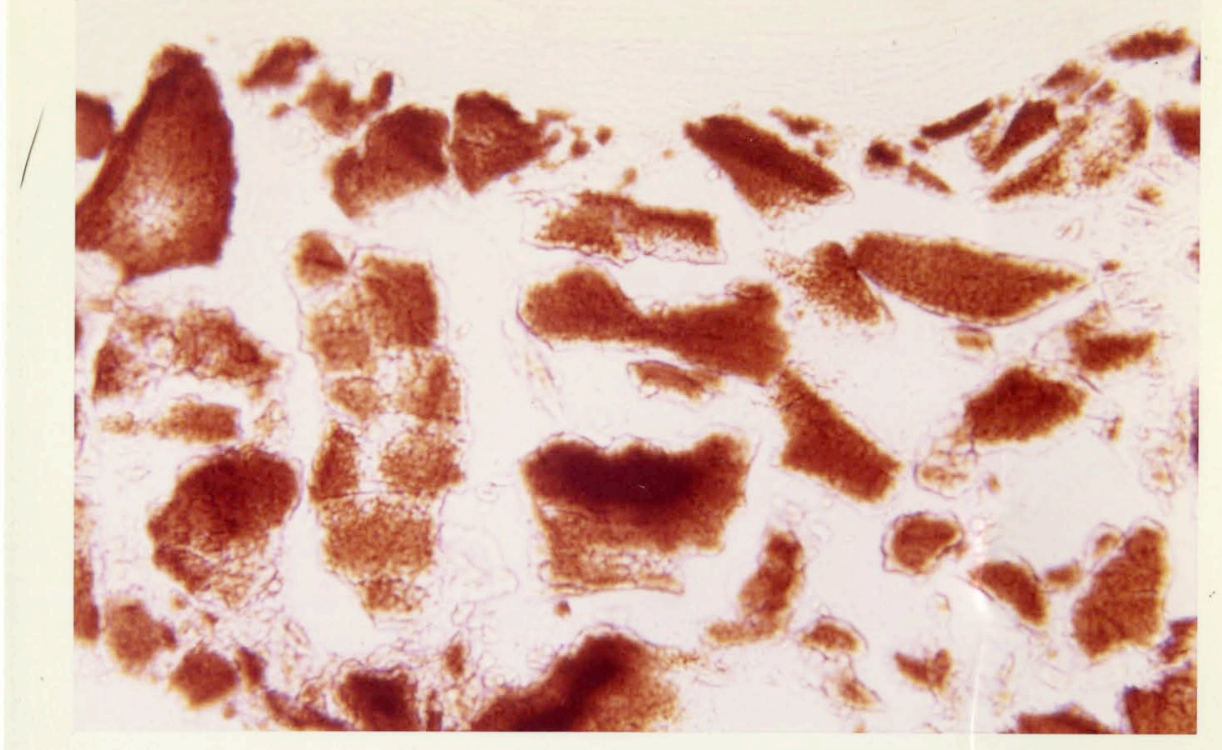

Figure 16

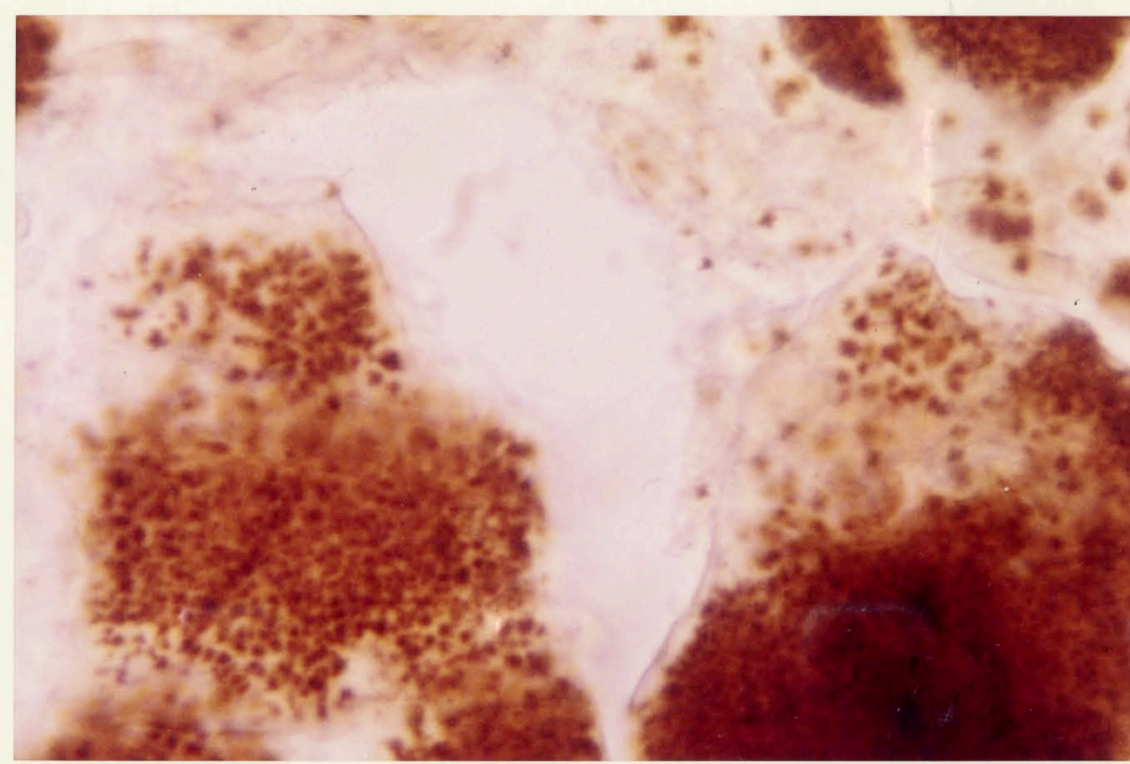

Figure 17

$6 \longdiv { \text { CHOOL ONA } }$ UNIVERSITY 


\section{APPROVAL SHEET}

The thesis submitted by Dr. John P. Giannini has been read and approved by four members of the Departments of Anatomy and Oral Anatomy.

The final copies have been examined by the director of the thesis and the signature which appears below verifies the fact that any necessary changes have been incorporated, and that the thesis is now given final approval with reference to content, form, and mechanical accuracy.

The thesis is therefore accepted in partial fulfillment of the requirements for the degree of Master of Science.
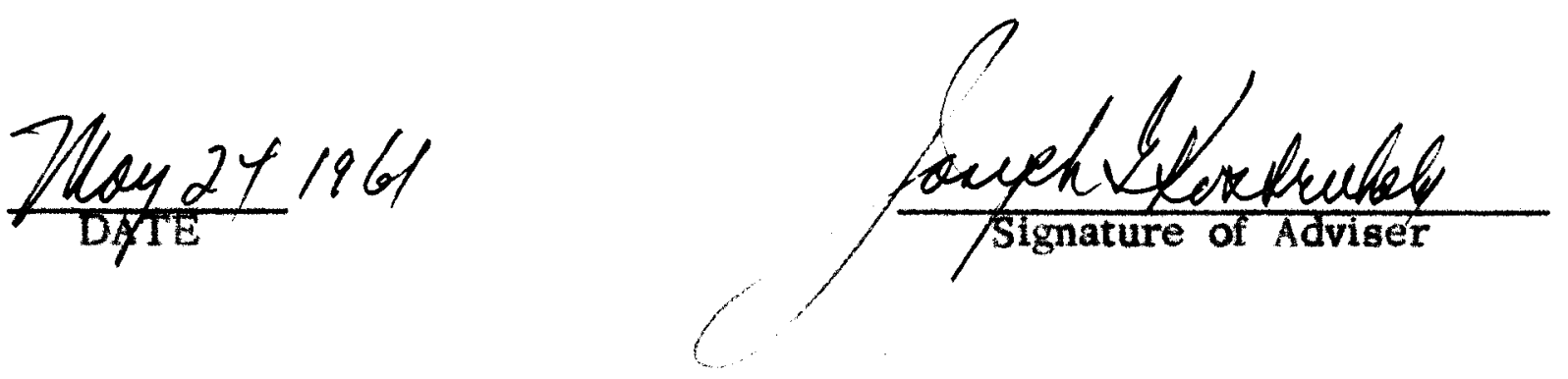